\title{
Nationwide Branching and its Impact on Market Structure, Quality and Bank Performance
}

\author{
Astrid A. Dick* \\ April 2003 \\ Forthcoming in the Journal of Business
}

\begin{abstract}
Based on a sample for 1993-1999, this paper examines the effects of nationwide branching, following the Riegle-Neal Act, on various aspects of banking markets and bank service and perfomance. While concentration at the regional level has increased dramatically, deregulation has left almost intact the market structure of urban markets, which have between two to three dominant firms -controlling over half of a market's deposits- in 1999 just as they did in 1993. A significant portion of the observed increase in bank quality can be traced to the implementation of nationwide branching. By allowing banks to open branches in any state, the new regime has permitted consumers to enjoy greater networks, free of fees, throughout large geographic regions. Consistent with an increase in service quality, costs and service fees increase. Credit risk increases as greater geographic diversification might provide a hedge against greater riskreturn choices. Coherent with these findings and an increase in lending competition and profit efficiency, spreads fall and profits are unaffected.
\end{abstract}

${ }^{*}$ Division of Research and Statistics, Federal Reserve Board; astrid.dick@frb.gov. This work is part of one of the chapters of the author's 2002 MIT PhD dissertation. She is grateful to Susan Athey and Nancy Rose for their guidance and support, as well as to Allen Berger and an anonymous referee for their suggestions. Any opinions and leftover errors are the author's. 


\section{Introduction}

During the last decade the banking industry in the U.S. experienced enormous changes in regulation and market composition. Banking markets have gone through a major process of consolidation, through thousands of mergers and acquisitions, entry and exit. Based on a sample for the period 1993-1999, this paper examines the effects of the passage of the Riegle-Neal Act, which allowed for nationwide branching in the U.S., on various aspects of banking markets and bank service and performance.

Assessing the effects of regulatory changes is a crucial part in the process of designing regulation. I examine here the effects of the implementation of nationwide branching on market structure and concentration, and service quality, as well as operating costs, loan portfolio quality, service prices and the banking rate of return. Given that banking markets usually hold dozens of firms, with many of them sharing very small portions of the market, I draw a distinction between dominant firms - who jointly hold over half of the market deposits - and fringe firms. While most of the analysis focuses on the relevant geographic banking market, defined at the level of the Metropolitan Statistical Area (MSA), I also examine some banking characteristics in larger geographic areas in order to draw comparisons between changes in urban areas and changes at higher levels of aggregation. Taking advantage of the variation in the dates in which states implemented nationwide branching throughout the four year period of 1994-1997, I estimate a linear specification in order to test for the statistical significance of the impact of deregulation on several bank and market characteristics, controlling for various factors.

Some research has suggested that geographic restrictions have been the most important factor in banking instability, by creating smaller banks and inhibiting diversification, thus making banks more vulnerable to economic downturns, bank runs and portfolio shocks [Calomiris 2000]. Following the lifting of geographic restrictions, there is work finding significant entry [Amel and Liang 1992; Calem 1994; McLaughlin 1995], as well as an improvement of economic and bank performance and efficiency, suggesting that branching restrictions have benefited smaller, less efficient banks by providing protection from competition of larger, more efficient firms that would enter were the barriers to entry lifted [Jayaratne and Strahan 1998, 1996; Kroszner and Strahan 1999; Stiroh and Strahan 2002]. This paper differs from the previous literature is a few ways. First, it focuses on the latter stage of deregulation, which consisted in nationwide branching, which has not been

previously studied. Second, it analyses not only the effects of deregulation on bank performance 
measures, but also on the impact of deregulation on market structure and service quality (the latter having been understudied in banking).

According to the results, while concentration at the regional level has increased dramatically, concentration at the urban level (MSA) has been virtually unaffected by deregulation. In fact, the basic market structure has been preserved, with urban markets having between two to three dominant firms in 1999 just as they did in 1993. Nevertheless, banks did react to nationwide branching and this has been reflected in a significant reduction in the number of firms controlling large geographic regions. In 1999 there is much more overlap in terms of the banks that control a region and those that control urban areas within that region, resulting in a lower variation of corporate identities across cities and towns within a region.

A significant portion of the observed increase in bank quality can be traced to the implementation of nationwide branching. By allowing banks to open branches in almost any state, ${ }^{1}$ the new regime has permitted consumers to enjoy greater networks, free of the inconvenience of fees, not only within their MSA market and state, but throughout larger geographic regions. Branch density also appears to increase following deregulation, as well as salary per employee, which suggests that banks have hired more highly skilled employees, who can provide better service and expertise.

Consistent with an increase in service quality, operating costs and service fees increase (as checking account consumers are likely to be the most sensitive to changes in quality) once geographic restrictions are fully lifted. Credit portfolio risk increases with deregulation, which might be explained by the enhanced hedge against greater risk-return combinations provided by greater geographic diversification. Spreads fall, which, in light of the increase in operating costs and risk, might be suggestive of an increase in competition in the lending market. Finally, as profit rates are unaffected throughout the period, all of these findings are in turn consistent with improved profit efficiency.

These results are particularly interesting in light of the argument usually held by those that opposed deregulation, on the one hand, as interstate branching would allegedly lead to a market outcome of a few, very large firms controlling large geographic areas in the country, with the corresponding detriments to consumers in local markets. While there has been a dramatic change in the market structure at the regional level, as expected, deregulation has left almost intact the structure of the relevant geographic markets. Regional dominant firms, while controlling large geographic areas, have not been able to "monopolize" urban markets (in the sense of becoming a

\footnotetext{
${ }^{1}$ Texas and Montana opted out of nationwide branching.
} 
market's sole dominant firm). ${ }^{2}$

On the other hand, as those that favored deregulation usually claimed, the full removal of geographic restrictions appears to have led to an increase in service quality, competition in the lending market, and profit efficiency, as less efficient banks might have been forced to reduce their market shares or even exit the market, allowing surviving banks to enjoy larger market volume. The findings are highly consistent with the increase in profit productivity and the decline in cost productivity in banking documented by Berger and Mester (2003) and Berger, Demsetz and Strahan (1999). In particular, Berger and Mester find that for the period 1991-1997, costs rise while revenues rise by more than the cost increase as banks might be providing higher quality services, particularly for banks engaging in mergers - many of which were allowed by nationwide branching. They argue that while providing new services and improving service quality raised costs significantly, firms maximized revenues by expanding or maintaining market shares and through higher prices.

The rest of the paper is organized as follows. Section 2 discusses briefly the regulatory regime and its changes throughout recent times, as well as providing some of the literature findings. Section 3 outlines the empirical framework of analysis, including the linear specification used to identify the impact of deregulation on various variables of interest. Section 4 describes the data. Sections 5, 6 and 7 analyze the impact of nationwide branching on market structure, service quality and bank performance, respectively. Finally, section 8 concludes.

\section{Banking deregulation and nationwide branching}

Throughout the last three decades, the industry has undergone several changes in both its composition and regulation. ${ }^{3}$ Regulatory restrictions ${ }^{4}$ affecting the ability of banks to diversify geographically and the range of products they may offer have decreased dramatically. Prior to the 1970s, all U.S. states forbade interstate branching, while intrastate branching was highly restrictive, with some states operating under the system of unit banking, which permitted banks to have no more than one full-service office. Deregulation of unit banking and limited branch banking occurred gradually throughout 1970-1994 in most states. Intrastate branching deregulation began in some

\footnotetext{
${ }^{2}$ Clearly, antitrust regulation should have played a role here.

${ }^{3}$ See Berger et al. (1995) for an extensive analysis of the U.S. banking industry throughout the period 1979-94, including a history of regulation.

${ }^{4}$ The main governmental organizations involved in the supervision and regulation of banking institutions are the Federal Reserve Board, the Federal Deposit Insurance Corporation (FDIC) and the Antitrust Division of the Justice Deparment.
} 
states even before the 1970's, while interstate banking started as early as $1978 .{ }^{5}$ Note that interstate banking permitted only out-of-state bank holding companies to acquire in-state banks. That is, it did not allow them to operate through their out-of-state bank name and branches.

The process of deregulation of geographic expansion culminated in 1994 with the passage of the Riegle-Neal Interstate Banking and Branching Efficiency Act, which permitted nationwide branching as of June 1997, and is the focus of this paper. States had the option to pass legislation to "opt in" earlier than the June 1997 federal deadline, which resulted in the Act becoming effective gradually among the U.S. states between 1994-1997. States were also allowed to pass legislation to opt out of the provisions for interstate branching, with Texas and Montana being the only states to do so. Table 1 chronicles the dates in which states passed the Riegle-Neal Act.

While the full removal of geographic restrictions started as late as 1994, the discussion about which regulatory framework is appropriate for the banking industry has been a central concern for regulators and firms alike for several decades. Those that have opposed deregulation in the past have frequently done so by alleging that interstate branching would lead to negative effects for consumers. Increased concentration through mergers and acquisitions, they argued, would lead to a market outcome of few, very large firms controlling many branches across large geographic regions of the U.S. In this setting, concentration has usually been interpreted as a negative feature of the industry. On the other hand, those that have favored deregulation have usually claimed that it would bring about an increase in competition and efficiency, with the corresponding benefits for consumers, and that the reason for the heavy regulation seen in the past has lain in the lobby pressure of mostly inefficient banks that profited from a regulated, and thus, less competitive environment.

A few papers analyze deregulation processes in banking related to the lifting of branching restrictions during the 1970s and 1980s. Kroszner and Strahan (1999) study the political economy related to the deregulation of bank branching restrictions for the period 1975-1991, ${ }^{6}$ and find that deregulation occurs later in states with relatively more small banks, which are inferred to be the main beneficiaries of the regulation. Stiroh and Strahan (2002) find that a bank's relative profit rate and its subsequent market share growth is strengthened after deregulation, and attribute this to the competitive reallocation effects that transfer assets to better performers, based on a sample from 1976 to 1994. Jayaratne and Strahan (1998) find that bank performance improves

\footnotetext{
${ }^{5}$ See Kroszner and Strahan (1999) for the specific dates by state of those deregulations.

${ }^{6}$ In particular, they analyze the removal of intrastate branching and interstate banking restrictions.
} 
significantly while costs and loan losses decrease sharply after restrictions on bank expansion are lifted. Jayaratne and Strahan (1996) find that a state's rate of real, per capita growth in income and output increase significantly following intrastate branch reform. Amel and Liang (1992) find that the lifting of branching restrictions increased new branch creation, but had little effect on de novo bank formation. Calem (1994) and McLaughlin (1995) obtain similar results, as they document significant entry following the lifting of branching restrictions.

\section{Empirical framework}

The passage of the Riegle-Neal Act enabled banks to have branches and buy other banking firms across the U.S. territory, therefore allowing for a dramatic change in the industry organization. Just a quarter of a century earlier, only fourteen states allowed statewide branching and not a single one permitted out-of-state banks to acquire in-state banks. Given this profound change in the regulatory regime, I explore whether nationwide branching affected the prevailing market structure in banking markets. Furthermore, I examine whether banks changed their performance in terms of costs, portfolio quality and profits once they were permitted to operate branch networks nationwide, as well as how much of these changes were passed on to the consumer in the form of service quality and prices.

In order to descriptively analyze how deregulation has affected market structure, I examine the data in several ways. First, I define two types of banking firms for a given urban area: dominant and fringe. Banking markets usually hold dozens of firms, yet many of these firms hold a very small portion of the market, naturally giving rise to an asymmetric oligopoly structure. As a result, it is relevant to make a distinction between the latter and those firms that head the market in terms of market share. In particular, dominant firms are defined as the set of firms that jointly hold over half of the market's deposits. All other firms are fringe firms. Second, while most of the analysis focuses on the relevant geographic market - defined as $\mathrm{MSA}^{7}-$, I examine some banking characteristics within larger geographic areas comprising several states, in order to draw comparisons between changes in urban areas and changes at higher levels of aggregation. For this purpose, I also define regional dominant firms as those that jointly hold over half of a region's deposits.

This analysis is complemented with the use of a linear specification to be estimated in order

\footnotetext{
${ }^{7}$ The data section of the paper discusses this choice of definition.
} 
to test for the statistical significance of the impact of deregulation on several market and bank characteristics, while controlling for various factors. Given that the relevant geographic market is thought to be local, the level of observation is defined at the MSA, with variation over time, in the analysis of market structure variables. In the analysis of quality and other bank characteristics, the unit of observation is defined at the state level, with variation over time, given that the regulatory environment does not vary across MSAs located in the same state. The dependent variable in this case is constructed as a state market share weighted average of all banks in the state in order to estimate the effects of deregulation on the "average" bank in the state. ${ }^{8}$

In constructing an indicator variable for nationwide branching deregulation (henceforth NWB), I use as a base the year in which a state passed the Riegle-Neal Act based on the dates chronicled in Table 1. Specifically, I create variables that take on the value of one: (i) the year the Act is passed in the state, and every year after that, and (ii) one, two and three years after the state passes the Act and every year after that (and zero otherwise). These indicator variables are created given that it should take time for bank restructuring to occur once the new regime is in place. They are constructed as indicated above, as opposed to single year effects, in order to capture the long-run effects of deregulation on trend, as opposed to the short-run effect. ${ }^{9}$

Using these deregulation indicators, I estimate the effects of the policy change on market structure variables with the following regression model:

$$
\begin{aligned}
y_{i, s, t} & =\beta_{1} N W B_{s, t} \\
& +\beta_{2} \text { OneYearAfter NWB }_{s, t}+\beta_{3} \text { TwoYearsAfter NWB }_{s, t}+\beta_{4} \text { ThreeYearsAfter } N W B_{s, t} \\
& + \text { Trend }_{t}+\text { State }_{s}+\text { Trend }_{t} \times \text { State }_{s}+\gamma_{i}+\epsilon_{i, s, t}
\end{aligned}
$$

where $y_{i, s, t}$ stands for one of several of the variables of interest related to market structure for MSA $i$ in state $s$ and year $t ; N W B_{s, t}$ is a deregulation indicator which takes the value of one starting the year in which state $s$ passed the Riegle-Neal Act, and similarly with OneYearAfter $N W B_{s, t}$,

\footnotetext{
${ }^{8}$ An alternative is to aggregate at the MSA level in order to estimate the effects of deregulation on the average MSA bank. This approach will also be used in the results section for robustness purposes. However, most bank data are available for the bank as a whole, and not for the bank in each MSA.

${ }^{9}$ It might be worth discussing here the possibility of endogeneity of deregulation. In a paper that investigates empirically alternative theories of regulatory change in the banking industry, Kroszner and Strahan (1999) find that restrictions on bank branching occurred earlier in states with relatively more large banks, which the authors infer had the most to gain from the deregulation. They conclude, therefore, that the private-interest approach has the greatest success in explaining such finding. In the current setup, the variables of interest have no direct relationship with bank size. If the latter existed, clearly, it would create inconsistent estimates from the model.
} 
Two YearsAfter $N W B_{s, t}$, and Three YearsAfter $N W B_{s, t}$, which take the value of one starting one, two and three years after the MSA's state passed the Act, respectively; Trend $_{t}$ is a time trend, which is allowed to vary by state through Trend $_{t} \times$ State $_{s} ;$ State $_{s}$ is a fixed effect for state $s ; \gamma_{i}$ measures the MSA specific component for MSA $i$, and $\epsilon_{i, s, t}$ is a random disturbance. The time trend and the MSA fixed effect are included in order to control for those factors that might affect the measures of market structure other than the change in regulation, such as technological innovations and demand factors. ${ }^{10}$

The effects of the policy change on bank quality and other bank characteristics are estimated with the following regression model, which is the same as (1) but with the unit of observation being a state*year combination:

$$
\begin{aligned}
& y_{i, t}=\beta_{1} N W B_{i, t} \\
& +\beta_{2} \text { OneYearAfter } N W B_{i, t}+\beta_{3} \text { TwoYearsAfter } N W B_{i, t}+\beta_{4} \text { ThreeYearsAfter } N W B_{i, t} \\
& + \text { Trend }_{t}+\text { State }_{i}+\text { Trend }_{t} \times \text { State }_{i}+\epsilon_{i, t}
\end{aligned}
$$

where $y_{i, t}$ stands for one of several of the variables of interest related to bank behavior for state $i$ in year $t$ (constructed as a deposit state market share weighted average); $N W B_{i, t}$ is a deregulation indicator which takes the value of one starting the year in which state $i$ passed the Riegle-Neal Act, and similarly with OneYearAfter $N W B_{i, t}$, Two YearsAfter $N W B_{i, t}$, and ThreeYearsAfterNWB $B_{i, t}$, which take the value of one starting one, two and three years after the state passed the Act, respectively; Trend $_{t}$ is a time trend, which is allowed to vary by state through Trend $_{t} \times$ State $_{i} ;$ State $_{i}$ is a fixed effect for state $i$, and $\epsilon_{i, t}$ is a random disturbance. The time trends are included in order to control for those factors that might affect the measures of bank behavior other than the change in regulation.

\footnotetext{
${ }^{10}$ Note that there are a few MSAs that cross state borders, and whose states have passed the Act in different years. Out of over $300 \mathrm{MSAs}$, there are $41 \mathrm{MSAs}$ whose area cover more than one state, and 21 of them belong to states that pass the legislation in different years. I deal with multi-state MSAs by assigning them to their most representative state, based on deposit share (which usually coincides with the state covering the largest geographic share of the MSA as well). The bulk of multi-state MSAs have, in fact, over 75 percent of the MSA deposits ocncentrated in a single state.
} 


\section{Data}

The data, which covers the period 1993-1999, are from several sources. ${ }^{11}$ The variables used in the analysis include: 1) bank characteristics, derived from balance sheet and income statement information from the Report on Condition and Income (Call Reports) from the Federal Reserve Board; 2) branch deposits, taken from the Federal Deposit Insurance Corporation (FDIC) Summary of Deposits; and 3) demographic variables, taken from the U.S. Census and the Bureau of Economic Analysis. The sample includes all metropolitan markets and all FDIC insured-commercial banks in the U.S. Table 2 shows summary statistics for the variables used in the analysis, while the Appendix has a description of the variables.

Given the format of the data, there are several possible levels of aggregation that could be used as the unit of analysis. My approach is to define the relevant geographic banking market at the level of the metropolitan statistical area (MSA), a geographic unit defined by the U.S. Census Bureau that consists of a large population nucleus, together with adjacent communities, that comprise one or more counties. This market definition is supported by surveys of consumers and businesses as well as the bulk of the empirical banking literature. ${ }^{12}$

\section{$5 \quad$ Nationwide branching and market structure}

The number of FDIC-insured commercial banks operating in U.S. urban markets decreased by about 1000 from 1993 to 1999 (from 5334 to 4333). This change took place through a series of mergers and acquisitions, as well as de novo entry and exit. Figure 1 shows the number of bank mergers per year since $1993 .{ }^{13}$ There is an average of 360 mergers per annum and the number of mergers per year decreases steadily since 1994. In terms of the average number of banks per MSA, there has been a slight reduction from 22 to 20 , as well as a decrease in the variance of the distribution (see Table 3). At the same time, the number of branches, even adjusting for population growth, has actually increased: the average number of branches per bank has increased from 8 to 13, the number of branches per bank within an MSA has gone from 6 to 7 , and the number of people per branch has decreased from over 5,000 to less than 4,600.

The distribution of the Herfindahl-Hirschman index (HHI) across MSA markets has remained

\footnotetext{
${ }^{11}$ The data are for the second quarter, which is chosen here because some the variables of interest are reported only then.

${ }^{12}$ For a detailed discussion on relevant geographic market definition, see Dick (2002a) and the references therein.

${ }^{13}$ The information on the figure is based on the author's calculation using Banking Holding Company data from the Federal Reserve Board.
} 
virtually unchanged, as evidenced in Table 4, with the average HHI across MSAs going from 1956 to 1924. Within the MSA, the concentration level in the counties that constitute an MSA has decreased slightly from an average of 3200 to 3100 (the median has gone from 2600 to less than 2500). This difference is not very large, indeed, but it could reflect that even when some markets in 1999 have fewer firms, banks might have more overlap or located closer to each other within a given market than they did in 1993.

Differentiating firms into dominant and fringe, as described earlier, a basic dominant-fringe firm market structure appears to have remained virtually unmodified. As depicted on Table 5, the majority of urban areas (over 80 percent) have between two to three dominant firms both at the beginning of the sample and at the end. There is a slight reduction in the number of fringe firms, with the mean across MSAs falling from 19 to 18 banks, and the variance decreasing as well. This can be observed in Table 6. However, the largest reduction in the size of the fringe happens in the largest markets, as measured by population size, and as depicted in Table 7 . In the smallest markets, the size of the fringe, as well as the total number of banks, increases slightly. It is also worth noting that surviving firms tend to be the larger banks who were able to expand into other markets, as well as increase their market shares in the MSA markets. The entrants and firms that exit, on the other hand, tend to be small, younger banks, that operate in only a few MSA markets and in a single state.

Figure 2 provides further evidence for the finding that the basic dominant-fringe firm structure remained unchanged since 1993. The figure contrasts the Lorenz curve of deposits in 1993 with that in 1999 for the Fort Lauderdale MSA, which is chosen as it is fairly representative of other MSA markets. In both years, the market remains rather concentrated, with about the same number of dominant firms. The fringe remains about the same size, going from 30 to 32 . It is clear from this figure that the basic market structure has not been affected throughout these seven years, even though there are some modifications in the tail of the distribution and the corporate identities of banks across the 1993-1999 period. This is the case throughout urban markets. For instance, the Boston MSA market, which is less representative of urban markets, experiencing a large reduction in the size of the fringe, still has between two to three dominant firms, a relatively large fringe and a fairly concentrated market in both 1993 and 1999. This is depicted in Figure 3.

The findings at higher levels of aggregation, however, tell a different story, with market structure having certainly changed. Dividing the U.S. territory into the nine regions described on Table $8,{ }^{14}$

\footnotetext{
${ }^{14}$ The regions include: New England, Middle Atlantic, East North Central, West North Central, Mountain, Pacific,
} 
where a region is a geographic area including several states, concentration has significantly increased in all of the nine regions since 1993. While there is great variation in terms of the levels of the HHI across regions, given their different population densities and the inclusion of money centers in some regions, the regional HHI has almost doubled on average, rising from roughly 400 in 1993 to over 700 in 1999. In some areas, such as the South Atlantic and the New England region, the HHI has increased several times in magnitude (from 150 to 750 in the South Atlantic and 600 to 1700 in New England).

Table 9 shows the number of dominant firms by region. The first two columns show the number of dominant firms that MSAs within the region have on average, for 1993 and 1999, respectively. The following four columns of the table show the number of regional dominant firms -those that jointly hold over half of the region's deposits. There are several important facts that can be inferred from this table. First, based on the first two columns of the table, the number of MSA dominant firms has remained virtually unchanged across regions, that is, between two to three as discussed earlier. Second, based on the third and fourth columns, the number of regional dominant firms has decreased dramatically in all of the nine regions, by an average of 55 percent. While in 1993 a region had on average 15 dominant firms, in 1999 there was an average of 8 dominant firms per region. Indeed, this is reflected in the significant increase in the regional HHI, as discussed earlier. Third, based on the fifth and sixth columns, the average number of banks that are dominant both at the regional and MSA level (within a given region) has increased in most regions. Given this increase in regional concentration as well as the decrease in the number of banks that dominate a given region, in 1999 there was much less variation across MSAs in terms of the corporate identities of the dominant banks in the market.

Figure 4, which shows a map of the New England region with its corresponding MSAs for the year 1999, provides further insight. ${ }^{15}$ From this figure one can appreciate that in 1999 the large majority of MSAs within the region had at least one bank that was dominant both at the regional and MSA level (BankBoston and Fleet). Another point worth noting from the figure is the amount of overlap between the two regional dominant firms across several MSA markets. ${ }^{16}$ These characteristics are even stronger in other U.S. regions.

Using the empirical model (1) outlined in section 3, I estimate the impact of nationwide branchWest South Central, East South Central, and South Atlantic.

${ }^{15}$ Figure 5 presents a similar map with the names of the MSAs within the New England region.

${ }^{16}$ In fact, soon after this paper's sample ends, Fleet became the dominant firm in four other MSAs in the New England region: Lewiston-Auburn, ME, Portland, ME, Portsmouth-Rochester, NH-ME, and Manchester, NH. 
ing on several variables related to market structure. Table 10 reports results from three specifications, including, as market structure attributes, the number of firms, the number of dominant firms, and the Herfindahl index in the MSA market, respectively. All the specifications control for a time trend, which is also state-specific, state and MSA fixed effects. In addition, standard errors are adjusted for within-state and year MSA dependence, as the idiosyncratic term of MSAs in any given state and year are expected to be correlated. Based on the results, the only significant effect from deregulation appears to be on the number of firms, shown in column (i), though the effect is rather small: the overall effect is an increase of about 4 firms on average. This is obtained by adding the (statistically significant) coefficients of all four of the indicator variables. The F-statistic for the sum of the deregulation indicators being equal to zero is rejected at the one percent level of confidence. Column (ii) of the table presents results from estimating the number of dominant firms as the dependent variable, where no significant effect is found from deregulation. Column (iii) provides the results for the estimation of the MSA Herfindahl index as a function of the deregulation indicators and other controls, and the results are similar in that there is no effect from deregulation.

These results simply reinforce our earlier findings that the basic market structure of MSA banking markets has stayed the same, notwithstanding nationwide branching. In fact, if anything has changed in this respect, it appears to be a slight increase in the number of firms in the average MSA market following deregulation.

These findings are particularly interesting in light of the argument usually held by those opposing deregulation, as interstate branching would allegedly lead to a market outcome of a few, very large firms controlling large geographic areas in the country with detriments to consumers in the local markets. While there has been a dramatic increase in concentration at the regional level, deregulation has left almost intact the market structure of the relevant geographic markets. ${ }^{17}$ In both 1993 and 1999, the average number of MSA dominant firms is 2.6, with only the size of the fringe varying in some instances, thus preserving the basic market structure of dominant firm-fringe throughout the period. Bank mergers, which occurred throughout the sample and represented one of the major vehicles for growth of these regional dominant firms, changed regional market structure

\footnotetext{
${ }^{17}$ Note, however, that more powerful regional dominant firms might be able to collude more easily through their multi-MSA market contact. Another point worth making is the following. Whenever there is a discussion in the literature about whether banking markets are larger than the MSA, the conclusion is usually that, if such is the case, it would be particularly true for business consumers. Based on the results here, deregulation could have given business consumers less bank variety - given the reduction of regional dominant firms- on the one hand, while perhaps providing them with more financing resources, on the other hand, as banks have greater ease in accesing funds (from banking holding companies as well as other sources, given their larger size).
} 
but left MSA market structure almost unchanged.

Given the shake-out in the industry throughout the nineties, with the implementation of nationwide branching, mergers, entry and exit, the finding that market structure at the local level stays the same throughout is rather striking. While part of this finding might be due to changes taking place before this paper's sample period through earlier branching deregulation at the state level, the finding is still remarkable in light of the possibilities that nationwide branching opened up for banks. The changes in the regional market structure might be expected to be attributable to the deregulation, since it was only through the removal of interstate branching restrictions that banks were able to expand to other states. In the next section we explore whether nationwide branching brought changes in bank quality.

\section{$6 \quad$ Nationwide branching and service quality}

In this section I analyze whether and how the passage of the Riegle-Neal Act of 1994 affected the level of service quality in banking markets. First of all, it is necessary to discuss bank quality and how it can be measured. The size of ATM (automated teller machines) and branch networks, the levels of expertise and customer care, the size and quality of branch personnel (which affect waiting times and the availability of human interaction), financial advise, as well as advertising/brand investments are aspects of banking services that are related to quality.

The data available do not allow for a complete and direct measure of bank quality, but some observable bank characteristics should provide an approximation. Following Dick (2002b), I use here several bank attributes as quality correlates, including: a bank's branch density in the MSA market, defined as the number of branches per square mile in the MSA; the number of employees per branch; the age of the bank, which might proxy for bank experience/branding; salary per employee; and the geographic diversification, measured as the number of states in which the bank operates.

Branch density and geographic diversification are expected to capture the quality of the overall bank network, as they are related to the number of branches in a bank's local markets and should be highly correlated with the ATM network as well. The number of employees per branch should capture some of the quality provided at the branch, since the larger the branch staff, the lower waiting times should be. While it is not possible to measure branding directly, bank age ${ }^{18}$ is

\footnotetext{
${ }^{18}$ While consumers might not be perfectly aware of a bank's age, they should be able to discern between relatively young and well-established, older banks.
} 
expected to be related to bank experience and its service quality, and/or the importance of branding, since a bank that has been around longer is more likely to have greater prestige and prominence than a younger bank. Expertise can be offered by any bank, but older banks might be particularly good if there is a learning curve. Older banks might know their customers better and therefore be able to custom fit their products better, therefore providing higher quality to the consumer. Salary paid to the bank's employees should be correlated with quality, as more highly skilled employees, who might provide better service and expertise, should be more expensive.

One would expect the lifting of geographic restrictions to affect at least the network size available to the consumer, as the new regime allowed banks to operate through branches across virtually the entire U.S. territory. As depicted in Table 11, since 1993 banks have increased their geographic coverage (the change being statistically significant at the one percent level of confidence, as indicated by the t-statistic provided in the table), with the number of a bank's states of operation increasing. In fact, the overall number of ATM terminals has increased dramatically since 1993, going from 94,822 to 227,000 in 1999 , as shown on Table 12 . This increase is true for both the number of terminals located within the premises of the branch as well as those located away from the branch (as stand-alone ATMs or ATMs inside supermarkets, for instance). Branch density and the number of employees per branch show little change. Banks also appear to pay higher salaries to their employees, and banks in 1999 are on average older than those in 1993.

Table 13 shows the results from estimating the quality attributes as a function of the deregulation indicators, as well as state fixed effects and a state-varying time trend (which allows for the case that bank quality is increasing or decreasing by a persistent amount each year in each state for reasons unrelated to deregulation). The dependent variable is aggregated to the state level, as a deposit share weighted average. ${ }^{19}$ All the regressions show an F-statistic for the test of whether the sum of the deregulation indicators equals zero. Based on these results, the number of states in which an average bank operates increases by almost 4 following deregulation (this is obtained by adding up the coefficients of the deregulation indicators). Branch density also appears to increase following deregulation, as well as the salary per employee (an increase of around $\$ 2,300$ ). All of these effects are statistically significant and the hypothesis that the sum of the deregulation indicators equals zero is rejected for all of these quality attributes. ${ }^{20}$

\footnotetext{
${ }^{19}$ The key results of this section and the next are robust to estimating the model at the level of aggregation of the MSA, as opposed to the state.

${ }^{20}$ Among other quality-related characteristics, banks also appear to serve, on average, a statisticaly significant larger number of rural areas in 1999.
} 
The above results suggest that a portion of the observed increase in bank quality can be traced to the implementation of nationwide branching, especially in terms of network size. By allowing banks to open up branches in any state, the new regime has allowed consumers to enjoy greater networks, not only within their MSA market and state, but throughout a larger region comprising several states, without having to deal with the inconvenience of inter-bank network fees ${ }^{21}$ and product/service differences. Bank age, which can be interpreted as an indicator of bank experience, appears to have increased, as the larger, older banks have been able to expand, usually at the expense of smaller, younger banks. Bank size, in fact, has also increased on average, and this might have translated into more diverse and/or specialized services that larger banks have a particular advantage in providing vis-à-vis smaller banks. ${ }^{22}$

\section{Nationwide branching and bank performance}

Some of the arguments frequently put forth by those who favor deregulation of an industry are related to the advantages derived from lower costs of production, greater efficiency, and lower prices. In this section I explore whether and how deregulation affected service prices, costs, performance, and risk.

Table 14 presents the mean and standard deviation for selected variables related to prices, costs, credit risk and profits for 1993 and 1999, before and after the implementation of nationwide branching, respectively. Loan prices decrease throughout the period, while deposit rates and fees increase. The overall effect, as measured by the banking spread, is a decrease of over half of a percentage point. Operating costs decrease slightly, as well as credit risk. While profit rates do not appear to change on average throughout the period, as measured by accounting profits in terms of equity, they do appear to be less dispersed in 1999 (the F-test for the equality of profit rate distribution is rejected at the 1 percent level of confidence).

In order to determine how these variables were affected by the change in regulation, I estimate each one as a function of deregulation indicators and other control variables, using the empirical model outlined in section 3 .

Prices

\footnotetext{
${ }^{21}$ Note that Cirrus and Plus national automated teller machine networks decided to allow ATM owners to collect usage fees from users in 1996, three years after the beginning of the sample used in this paper.

${ }^{22}$ Using a discrete choice approach, Dick (2002a) estimates a deposit demand function, derived from the consumer's utility function, which includes some of the quality attributes analyzed in this paper, and finds a consumer welfare increase for the period 1993-1999 in most MSA markets.
} 
Prices are imputed using the flow data from the income statement and the corresponding stocks from the balance sheet. Table 15 reports estimates of changes in various prices following deregulation. The models for the loan and deposit rates include the level of the market interest rate (6-month Treasury bill) as an explanatory variable. Note that the market rate is significant and positive for both the loan and deposit rates. While loan rates decrease by 0.2 percentage point following deregulation, deposit rates increase by 0.3 percentage points. ${ }^{23}$ Jayaratne and Strahan (1997) also find a decrease in loan rates following earlier stages of deregulation (though they find no effect on deposit rates). Service fees on checking accounts show a slight increase of 0.005 percentage points.

The net effect of all these price changes is reflected in column (iv) of table 15, where the spread, defined as the difference between the prices charged and those paid by the bank, is also estimated as a function of the deregulation indicators and the rest of the control variables. ${ }^{24}$ Banking spreads appear to decrease by about 0.6 percentage points as a result of deregulation, based on the sum of the statistically significant effects during the three years after deregulation. At this point it is difficult to infer the implications of this result, such as whether it translated into a pricing advantage for consumers or financial intermediation improvements, since the spread is composed of several parts, including risk, operating costs, and market power, all of which might have been changing. However, the decrease in the spread, along with the decrease in loan rates and the increase in deposit rates, on the one hand, could be indicative of an increase in competition for these products. On the other hand, the increase in service fees is consistent with the earlier finding of an increase in bank quality, as checking account consumers, who might care a lot about their bank's service characteristics and also be different from loan customers, would then be willing to pay more for a better service (checking accounts customers, in fact, are likely to be the consumer segment most sensitive to both horizontal and vertical differentiation).

\section{Costs}

Operating costs are measured by noninterest expenses over assets. Table 16 reports the results for estimating the effects of branching deregulation on these costs. Costs appear to increase by one percentage point following deregulation. If banks are providing better service, as found earlier, through more extensive branching and ATM networks allowed by the new regulatory regime, as

\footnotetext{
${ }^{23}$ In order to obtain a figure for what this change represents in monetary units, one could multiply this estimate by the amount of total loans outstanding or deposits, respectively.

${ }^{24}$ In particular, I define the spread as: interest rate on loans + service fees - interest rate on deposits.
} 
well as paying higher salaries to their employees - all of which affect the measure of cost used here -, operating costs should increase. In fact, a large part of the increase in costs is accounted for by the increase in salary expense, as well as (though to a lesser extent), an increase in expenses on premises and fixed assets (such as equipment and furniture and other maintenance), ${ }^{25}$ both of which are consistent with bank expansion and better service. These results do not rule out, however, improvements in production efficiency derived from the enhanced geographic expansion which might have allowed banks to exploit certain efficiencies derived from scale in network. Indeed, the time trend indicates that costs decrease throughout the period.

\section{Portfolio risk}

Risk from the loan portfolio is measured by charged-off losses over loans. ${ }^{26}$ This risk appears to increase by 0.4 percentage points following deregulation, even though, on average, it decreases from 1993 to 1999, as evidenced by the trend (which could be related to technological innovations in credit risk analysis). One possible explanation for this result is that banks might have used their greater geographic diversification as a hedge against a greater risk-return choice. Alternatively, as nationwide branching allowed for a process of mergers and acquisitions which affected the identities of the firms operating in banking markets, the new set of banks could have different risk preferences that have led them to choose a different mix of loan product niches. This result is different from what Jayaratne and Strahan (1996) find, who document a decrease in risk of similar magnitude following earlier stages of deregulation (involving mostly within-state branching restrictions). ${ }^{27}$

\section{Performance}

Bank performance is measured by accounting profits adjusted by net worth. While this is an imperfect measure of the true rate of return, it is still a reasonable indicator of how banks are faring in the business. ${ }^{28}$ According to the results reported in Table 16, none of the changes in the rate of return can be traced to the change in regulation.

The fact that profit rates do not change on average throughout the period is particularly interesting as this is coupled with an increase in operating costs and credit risk as well as a decrease in spreads following the implementation of nationwide branching. The geographic expansion enjoyed

\footnotetext{
${ }^{25}$ Results not shown.

${ }^{26}$ Results are qualitatively and quantitatively robust to using loan loss provisions instead of charge-offs.

${ }^{27}$ The authors do not control for time trends, however, and as a result it might be harder to discern between changes due to deregulation per se and those related to other trends.

${ }^{28}$ See Fisher and McGowen (1983) for a discussion of problems related to the use of accounting rates of return.
} 
by many banks might have led to an increase in profit efficiency, as less efficient banks might have been forced to reduce their market shares or even exit the market, allowing surviving banks to enjoy larger market volume.

In summary, consistent with an increase in service quality, operating costs and service fees increase (as checking account consumers are likely to be the most sensitive to changes in quality). Greater geographic diversification provides banks with a hedge against greater risk-return combinations, and this might explain the increase in credit risk. The finding that operating costs and risk increase while spreads fall might be suggestive of an increase in competition in the lending market. Finally, as profit rates are unaffected throughout the period, all of these findings are in turn consistent with improved profit efficiency. Berger and Mester (2003) find a substantial improvement in profit productivity throughout 1991-1997, and argue that while providing new services and improving service quality raised costs significantly, firms maximized revenues by expanding or maintaining market shares, larger geographic diversification, and higher prices.

\section{Concluding remarks}

This paper examined the effects of the passage of the 1994 Riegle-Neal Act, which allowed for nationwide branching in the U.S., on various aspects of banking markets and bank service and performance. The results suggest that deregulation has left the relevant geographic banking market virtually intact, with urban markets having between two to three dominant firms in 1999 just as they did in 1993, with no change in local concentration. Banks did respond to nationwide branching, however, but this shows in the increase in concentration in larger geographic areas covering several states, as well as an increase in service quality, through extensive branching and ATM networks.

Consistent with the increase in service quality, operating costs and service fees increase, as checking account consumers are likely to be the most sensitive to changes in quality. Intermediation spreads fall following deregulation, which, coupled with the finding that operating costs and risk increase, might be suggestive of an increase in competition in the lending market.

The geographic expansion allowed by the deregulation has likely enhanced the environment for banks in several ways. First, greater geographic diversification provides banks with a hedge against greater risk-return combinations, and this might explain the increase in credit risk. Second, it has probably also led to an increase in profit efficiency, as less efficient banks might have been forced to reduce their market shares or even exit the market, allowing surviving banks to enjoy larger 
market volume. Indeed, this could explain why profit rates are unaffected throughout the period when costs are rising and spreads falling. These results are consistent with the findings of Berger and Mester (2003) and Berger, Demsetz and Strahan (1999) who document an increase in profit productivity and a decline in cost productivity during the 1990s.

While those that have traditionally opposed deregulation, on the one hand, feared an increase in market concentration, concentration in the relevant market remained virtually unaffected by nationwide branching. On the other hand, the full removal of geographic restrictions appears to have led to an increase in lending competition and profit efficiency through greater market volume - as those that have favored deregulation usually claimed-, as well as some benefits to consumers, as banks increased their service quality, which translated into larger, free of fees networks for consumers.

In terms of future research, it would be interesting to analyze whether the finance-growth nexus found to exist during earlier stages of deregulation, still applies (see Jayaratne and Strahan, 1996). In other words, has nationwide branching deregulation affected not only the banking industry but also the rate of income and output growth of the economy? If so, through what channels, other than those studied here - such as small business lending - did it have an effect?

\section{References}

[1] Amel, D. F. and N.J. Liang (1992). "The Relationship between Entry into Banking Markets and Changes in Legal Restrictions on Entry." Antitrust Bulletin, 37:631-649.

[2] Berger, A.N., R.S. Demsetz and P.E. Strahan (1999). "The consolidation of the financial services industry: Causes, consequences, and implications for the future." Journal of Banking and Finance, 23:135-194.

[3] Berger, A.N, A.K. Kashyap and J.M. Scalise (1995). "The Transformation of the U.S. Banking Industry: What a Long, Strange Trip It's Been." Brooking Papers on Economic Activity, 2:55218.

[4] Berger, A.N. and L.J. Mester (1997). "Inside the Black Box: What Explains Differences in the Efficiencies of Financial Institutions?" Journal of Banking and Finance, 21:895-947. 
[5] Berger, A.N. and L.J. Mester (2003). "Explaining the dramatic changes in performance of US banks: Technological change, deregulation, and dynamic changes in competition." Journal of Financial Intermediation, forthcoming.

[6] Calem, P. (1994). "The impact of geographic deregulation on small banks." Business Review, Federal Reserve Bank of Philadelphia.

[7] Calomiris, C.W. (2000). U.S. Bank Deregulation in Historical Perspective. New York: Cambridge University Press.

[8] Dick, A.A. (2002a). "Demand Estimation and Consumer Welfare in the Banking Industry." Finance and Economics Discussion Series, Federal Reserve Board, 2002-58.

[9] Dick, A.A. (2002b). "Market Structure and Quality: An Application to the Banking Industry." Finance and Economics Discussion Series, Federal Reserve Board, 2003-14.

[10] Fisher, F.M. and J.J. McGowen (1983). "On the Misuse of Accounting Rates of Return to Infer Monopoly Profits." American Economic Review, 73:82-97.

[11] Kroszner, R.S. and P.E. Strahan (1999). "What Drives Deregulation? Economics and Politics of the Relaxation of Bank Branching Restrictions." Quarterly Journal of Economics, 114:143767.

[12] Jayaratne, J. and P.E. Strahan (1996). "The Finance-Growth Nexus: Evidence from Bank Branch Deregulation." Quarterly Journal of Economics, 111:639-670.

[13] Jayaratne, J. and P.E. Strahan (1998). "Entry Restrictions, Industry Evolution, and Dynamic Efficiency: Evidence from Commercial Banking." The Journal of Law and Economics, 41:239273.

[14] McLaughlin, S. (1995). "The impact of interstate banking and branching reform: evidence from the state." Current Issues in Economics and Finance, Federal Reserve Bank of New York, Vol. 1, No. 2.

[15] Shaked, A. and J. Sutton (1987). "Product Differentiation and Industrial Structure." Journal of Industrial Economics, 36:131-146.

[16] Stiroh, K.J. and P.E. Strahan (2002). "Competitive Dynamics of Deregulation: Evidence from U.S. Banking”. Journal of Money, Credit and Banking, forthcoming. 
[17] Sutton, J. (1991). Sunk Cost and Market Structure: Price Competition, Advertising, and the Evolution of Concentration. Cambridge: MIT Press. 
Table 1: DATE OF PASSAGE OF RIEGLE-NEAL ACT OF 1994, BY STATE

\begin{tabular}{|c|c|}
\hline State & Date \\
\hline Alabama & $5 / 31 / 97$ \\
\hline Alaska & $1 / 1 / 94$ \\
\hline Arizona & $8 / 31 / 96$ \\
\hline Arkansas & $5 / 31 / 97$ \\
\hline California & $10 / 2 / 95$ \\
\hline Colorado & $6 / 1 / 97$ \\
\hline Connecticut & $6 / 27 / 95$ \\
\hline Delaware & $9 / 29 / 95$ \\
\hline District of Columbia & $6 / 13 / 96$ \\
\hline Florida & $5 / 31 / 97$ \\
\hline Georgia & $6 / 1 / 97$ \\
\hline Hawaii & $6 / 1 / 97$ \\
\hline Idaho & $7 / 1 / 95$ \\
\hline Illinois & $6 / 1 / 97$ \\
\hline Indiana & $3 / 15 / 96$ \\
\hline Iowa & $3 / 27 / 96$ \\
\hline Kansas & $6 / 1 / 97$ \\
\hline Kentucky & $6 / 1 / 97$ \\
\hline Louisiana & $6 / 1 / 97$ \\
\hline Maine & $1 / 1 / 97$ \\
\hline Maryland & $9 / 29 / 95$ \\
\hline Massachusetts & $8 / 2 / 96$ \\
\hline Michigan & $11 / 29 / 95$ \\
\hline Minnesota & $6 / 1 / 97$ \\
\hline Mississippi & $5 / 1 / 97$ \\
\hline Missouri & $6 / 1 / 97$ \\
\hline Montana & $3 / 21 / 97$ \\
\hline Nebraska & $5 / 31 / 97$ \\
\hline Nevada & $9 / 28 / 95$ \\
\hline New Hampshire & $6 / 1 / 97$ \\
\hline New Jersey & $4 / 17 / 96$ \\
\hline New Mexico & $6 / 1 / 96$ \\
\hline New York & $2 / 6 / 96$ \\
\hline North Carolina & $6 / 22 / 95$ \\
\hline North Dakota & $5 / 31 / 97$ \\
\hline Ohio & $5 / 22 / 97$ \\
\hline Oklahoma & $5 / 31 / 97$ \\
\hline Oregon & $2 / 27 / 95$ \\
\hline Pennsylvania & $7 / 6 / 95$ \\
\hline Rhode Island & $6 / 20 / 95$ \\
\hline South Carolina & $7 / 1 / 96$ \\
\hline South Dakota & $7 / 1 / 96$ \\
\hline Tennessee & $6 / 1 / 97$ \\
\hline Texas & $8 / 28 / 95$ \\
\hline Utah & $6 / 1 / 95$ \\
\hline Vermont & $5 / 30 / 96$ \\
\hline Virginia & $7 / 1 / 95$ \\
\hline Washington & $6 / 6 / 96$ \\
\hline West Virginia & $5 / 31 / 97$ \\
\hline Wisconsin & $6 / 1 / 97$ \\
\hline Wyoming & $5 / 31 / 97$ \\
\hline
\end{tabular}


Table 2: SUMMARY STATISTICS: BANKING FIRMS, 1993-1999

\begin{tabular}{|c|c|c|c|c|}
\hline Variable & Mean & St. Dev. & Min & Max \\
\hline Bank assets & $1.96 \mathrm{~B}$ & $15.40 \mathrm{~B}$ & $3 \mathrm{M}$ & $323 \mathrm{~B}$ \\
\hline State deposits & $448 \mathrm{M}$ & $2442 \mathrm{M}$ & 2000 & $98 \mathrm{~B}$ \\
\hline Cash / Assets & 0.0566 & 0.0403 & 0.0004 & 0.7880 \\
\hline Federal funds + securities / Assets & 0.3176 & 0.1417 & 0.0000 & 0.9919 \\
\hline Real estate loans / Assets & 0.3541 & 0.1421 & 0.0000 & 0.9422 \\
\hline Loans to individuals / Assets & 0.0879 & 0.0817 & 0.0000 & 1.0690 \\
\hline Commercial $\mathcal{E}$ industrial loans / Assets & 0.1161 & 0.0829 & 0.0000 & 0.8159 \\
\hline Commitment lines / Loans & 0.2324 & 0.9959 & 0.0000 & 120.31 \\
\hline Time deposits over $\$ 100,000 /$ Deposits & 0.0923 & 0.0652 & 0.0000 & 0.8266 \\
\hline Equity / Assets & 0.0959 & 0.0403 & -0.0625 & 0.8306 \\
\hline Employees per branch & 29 & 235 & 0 & 13891 \\
\hline Branch density & 0.0030 & 0.0074 & 0.0000 & 0.2483 \\
\hline Bank's age & 55 & 42 & 0 & 215 \\
\hline Salary per employee & 36,416 & 12,545 & 0 & $1,087,750$ \\
\hline Number of states in which the bank operates & 1.13 & 1.03 & 1.00 & 17.00 \\
\hline Bank operates in at least one rural area $(1=y e s)$ & 0.2397 & 0.4269 & 0.0000 & 1.0000 \\
\hline Loan interest rate & 0.0894 & 0.0175 & 0.0004 & 1.6364 \\
\hline Deposit interest rate & 0.0311 & 0.0085 & 0.0000 & 0.1718 \\
\hline Service fees & 0.0058 & 0.0062 & 0.0000 & 0.3054 \\
\hline Operating costs / Assets & 0.0362 & 0.0162 & 0.0000 & 0.4919 \\
\hline Charge-off loans / Loans & 0.0021 & 0.0059 & 0.0000 & 0.6374 \\
\hline Loan loss provisions / Loans & 0.0018 & 0.0103 & -1.6122 & 0.3604 \\
\hline Profits / Equity & 0.1180 & 0.1145 & -1.9757 & 1.5787 \\
\hline Number of observations (bank* state* year) & 33211 & & & \\
\hline
\end{tabular}

Constructed on the basis of the Federal Reserve Report on Condition and Income;

U.S. Census; Bureau of Economic Analysis. 
Table 3: NUMBER OF FIRMS PERCENTILES ACROSS MSA MARKETS

\begin{tabular}{lccccccc}
\hline \hline & $5 \%$ & $10 \%$ & $25 \%$ & Median & $75 \%$ & $90 \%$ & $95 \%$ \\
\hline 1993 (Before NWB) & & & & & & & \\
Number of banks (Mean=22) & 6 & 7 & 9 & 14 & 21 & 42 & 63 \\
Number of branches (Mean=131) & 18 & 23 & 34 & 58 & 129 & 303 & 437 \\
1999 (After NWB) & & & & & & & \\
Number of banks (Mean=20) & 6 & 7 & 10 & 14 & 22 & 37 & 54 \\
Number of branches (Mean=140) & 19 & 27 & 39 & 67 & 152 & 343 & 516 \\
& & & & & & & \\
\hline
\end{tabular}

NOTE.- NWB: Nationwide branching deregulation. 
Table 4: HERFINDAHL INDEX PERCENTILES ACROSS MSA MARKETS (1993 V. 1999)

\begin{tabular}{cccccccc}
\hline \hline & $5 \%$ & $10 \%$ & $25 \%$ & Median & $75 \%$ & $90 \%$ & $95 \%$ \\
\hline $\begin{array}{c}1993 \text { (Before NWB) } \\
\text { Mean }=1956\end{array}$ & 915 & 1100 & 1421 & 1847 & 2335 & 2909 & 3248 \\
$\begin{array}{c}1999 \text { (After NWB) } \\
\text { Mean }=1924\end{array}$ & 934 & 1124 & 1432 & 1793 & 2240 & 2817 & 3417 \\
\hline NOTE.- Based on deposit shares. NWB: Nationwide branching deregulation.
\end{tabular}


Table 5: MSA MARKETS BY NUMBER OF DOMINANT FIRMS BEFORE AND AFTER NATIONWIDE BRANCHING

\begin{tabular}{crrrr}
\hline \hline & \multicolumn{2}{c}{1993} & \multicolumn{2}{c}{1999} \\
\cline { 2 - 5 } $\begin{array}{c}\text { Number of } \\
\text { dominant firms }\end{array}$ & Freq. & $\%$ & Freq. & $\%$ \\
\hline 1 & 9 & 2.9 & 14 & 4.2 \\
2 & 169 & 54.7 & 158 & 47.7 \\
3 & 87 & 28.2 & 114 & 34.4 \\
4 & 30 & 9.7 & 33 & 10.0 \\
5 & 7 & 2.3 & 8 & 2.4 \\
6 & 5 & 1.6 & 3 & 0.9 \\
7 & 0 & 0.0 & 1 & 0.3 \\
8 & 0 & 0.0 & 0 & 0.0 \\
9 & 2 & 0.6 & 0 & 0.0
\end{tabular}

Total MSAs $\quad 309 \quad 331$

NOTE.- Dominant firms are those that jointly hold over half of the market's deposits. All other firms are fringe firms. 
Table 6: SIZE OF FRINGE PERCENTILES ACROSS MSA MARKETS (1993 V. 1999)

\begin{tabular}{cccccccc}
\hline \hline & $5 \%$ & $10 \%$ & $25 \%$ & Median & $75 \%$ & $90 \%$ & $95 \%$ \\
\hline 1993 (Before NWB) & 4 & 5 & 7 & 11 & 18 & 40 & 59 \\
$\begin{array}{c}\text { Mean }=19 \\
1999 \quad \text { (After NWB) } \\
\text { Mean }=18\end{array}$ & 4 & 5 & 7 & 11 & 20 & 34 & 50 \\
\hline
\end{tabular}

NOTE.- NWB: Nationwide branching deregulation. Dominant firms are those that jointly hold over half of the market's deposits. All other firms are fringe firms. 
Table 7: FRINGE AND TOTAL NUMBER OF FIRMS BY MARKET SIZE, 1993 V. 1999

\begin{tabular}{|c|c|c|c|c|}
\hline \multirow[t]{2}{*}{ Population } & \multicolumn{2}{|c|}{$\begin{array}{l}\text { Avg. fringe } \\
\text { size }\end{array}$} & \multicolumn{2}{|c|}{$\begin{array}{l}\text { Avg. number } \\
\text { of MSA firms }\end{array}$} \\
\hline & 1993 & 1999 & 1993 & 1999 \\
\hline $100 \mathrm{~K}$ or less & 5.6 & 6.5 & 7.6 & 8.5 \\
\hline $100 K-200 K$ & 8.4 & 8.7 & 10.8 & 11.4 \\
\hline $200 K-500 K$ & 12.6 & 12.5 & 15.4 & 15.3 \\
\hline $500 K-1 M$ & 19.7 & 17.3 & 22.4 & 20.0 \\
\hline $1 M-2 M$ & 37.0 & 32.0 & 39.7 & 34.6 \\
\hline $2 M+$ & 84.4 & 68.2 & 87.7 & 70.8 \\
\hline Average & 19.2 & 17.7 & 21.8 & 20.3 \\
\hline
\end{tabular}


Table 8: U.S. REGIONS

\begin{tabular}{llrr}
\hline \hline & & \multicolumn{2}{c}{ HHI } \\
\cline { 2 - 4 } Region & \multicolumn{1}{c}{ States } & 1993 & 1999 \\
\hline East North Central & IL, IN, MI, OH, WI & 318 \\
East South Central & AL, KY, MS, TN & 309 & 379 \\
Middle Atlantic & NJ, NY, PA & 376 & 634 \\
Mountain & AZ, CO, ID, MT, NM, NV, UT, WY & 370 & 501 \\
New England & CT, MA, ME, NH, RI, VT & 593 & 1712 \\
Pacific & AK, CA, HI, OR, WA & 1176 & 1380 \\
South Atlantic & DC, DE, FL, GA, MD, NC, SC, VA, WV & 146 & 760 \\
West North Central & IA, KS, MN, MO, ND, NE, SD & 226 & 383 \\
West South Central & AL, KY, MS, TN & 337 & 439 \\
\hline
\end{tabular}

NOTE.- HHI (Herfindahl Index) is based on deposit shares. 
Table 9: DOMINANT FIRMS AT REGIONAL AND MSA LEVEL, 1993 V. 1999

\begin{tabular}{|c|c|c|c|c|c|c|}
\hline \multirow[t]{2}{*}{ U.S. Region } & \multicolumn{2}{|c|}{$\begin{array}{l}\text { Avg. number of } \\
\text { MSA dominant } \\
\text { firms }\end{array}$} & \multicolumn{2}{|c|}{$\begin{array}{l}\text { Number of } \\
\text { regional dominant } \\
\text { firms }\end{array}$} & \multicolumn{2}{|c|}{$\begin{array}{l}\text { Avg. number } \\
\text { of regional dom. } \\
\text { firms in MSA }\end{array}$} \\
\hline & 1993 & 1999 & 1993 & 1999 & 1993 & 1999 \\
\hline New England & 2.1 & 1.8 & 6 & 2 & 1.7 & 1.4 \\
\hline Middle Atlantic & 2.6 & 2.6 & 10 & 6 & 2.5 & 2.2 \\
\hline East North Central & 2.8 & 2.9 & 32 & 18 & 1.9 & 2.8 \\
\hline West North Central & 2.6 & 2.6 & 21 & 10 & 1.0 & 2.2 \\
\hline Mountain & 2.5 & 2.5 & 10 & 7 & 1.7 & 2.3 \\
\hline Pacific & 2.1 & 2.4 & 4 & 3 & 2.3 & 2.5 \\
\hline West South Central & 3.0 & 2.9 & 17 & 9 & 2.4 & 2.8 \\
\hline East South Central & 2.6 & 3.0 & 11 & 9 & 2.7 & 3.5 \\
\hline South Atlantic & 2.7 & 2.6 & 28 & 6 & 3.0 & 2.9 \\
\hline Average & 2.6 & 2.6 & 15.4 & 7.8 & 2.3 & 2.6 \\
\hline
\end{tabular}

NOTE.- MSA dominant firms are those that jointly hold over half of the MSA's deposits. Regional dominant firms are those that jointly hold over half of the region's deposits. 
Table 10: OLS REGRESSIONS OF THE EFFECT OF BRANCHING DEREGULATION ON MARKET STRUCTURE

\begin{tabular}{lccc}
\hline \hline & \multicolumn{3}{c}{ Dependent Variable } \\
\cline { 2 - 4 } & $\begin{array}{c}\text { Number of } \\
\text { Eirms }\end{array}$ & $\begin{array}{c}\text { Number of } \\
\text { dominant firms }\end{array}$ & $\begin{array}{c}\text { Herfindahl } \\
\text { Index }\end{array}$ \\
\cline { 2 - 4 } Explanatory Variable & $(\mathrm{i})$ & (ii) & (iii) \\
\hline$N W B$ & 0.652 & -0.023 & 0.000 \\
& $(0.235) * *$ & $(0.038)$ & $(0.002)$ \\
One year after $N W B$ & 0.619 & 0.004 & 0.004 \\
Two years after $N W B$ & $(0.195) * *$ & $(0.038)$ & $(0.003)$ \\
Three years after $N W B$ & 0.991 & -0.026 & -0.001 \\
& $(0.217) * *$ & $(0.040)$ & $(0.003)$ \\
Time trend & 1.719 & 0.055 & -0.003 \\
& $(0.348) * *$ & $(0.040)$ & $(0.004)$ \\
& -0.868 & -0.004 & 0.004 \\
F-statistic & $(0.127) * *$ & $(0.016)$ & $(0.002) \dagger$ \\
Observations & & & \\
R-squared & & & 0.01 \\
& $22.22^{* *}$ & 0.01 & 2275 \\
& & & 0.87 \\
\hline
\end{tabular}

NOTES.-

1. NWB: Nationwide branching deregulation indicator which takes the value of one starting the year in which the state passes the Riegle-Neal Act.

2. Sample: 1993-1999.

3. An observation is an MSA*state*year combination.

4. The dependent variable is a deposit market share weighted average of all banks in a given MSA.

5. Dominant firms are those that jointly hold over half of the MSAs deposits.

6. All regressions include MSA fixed effects, state fixed effects and a statespecific trend.

7. Value of F-statistic for the test of whether the sum of the deregulation indicators equals zero.

8. Estimated standard errors, in parentheses, are clustered by state*year to control for within state*year MSA dependence.

9. †significant at $10 \%$; *significant at $5 \%$; ** significant at $1 \%$. 
Table 11: QUALITY ATTRIBUTES: 1993 V. 1999

\begin{tabular}{|c|c|c|c|c|c|}
\hline \multirow[b]{2}{*}{ Variable } & \multicolumn{2}{|c|}{1993} & \multicolumn{2}{|c|}{1999} & \multirow[b]{2}{*}{ T-stat } \\
\hline & Mean & St. Dev. & Mean & St. Dev. & \\
\hline Employees per branch & 31.95 & 208.92 & 30.26 & 254.00 & -0.36 \\
\hline Branch density & 0.0029 & 0.0084 & 0.0031 & 0.0075 & 1.32 \\
\hline Bank's age & 51.01 & 40.47 & 55.91 & 43.38 & 5.82 \\
\hline Salary per employee & 32,900 & 24,260 & 42,140 & 14,960 & 22.37 \\
\hline Number of states & 1.00 & 0.09 & 1.40 & 1.84 & 15.53 \\
\hline Observations & 5293 & & 4536 & & \\
\hline
\end{tabular}

NOTE.- The unit of observation is a bank* state* $^{*}$ year combination. 
Table 12: ATM TERMINALS

\begin{tabular}{rrr}
\hline \hline Year & $\begin{array}{c}\text { Total } \\
\text { terminals }\end{array}$ & Off-premise \\
\hline & & \\
1993 & 94,822 & $\mathrm{~N} / \mathrm{A}$ \\
1994 & 109,080 & 28,707 \\
1995 & 122,706 & 37,804 \\
1996 & 139,134 & 51,207 \\
1997 & 165,000 & 67,000 \\
1998 & 187,000 & 84,000 \\
1999 & 227,000 & 117,000 \\
& & \\
\hline
\end{tabular}

Source: Bank Network News. 
Table 13: OLS REGRESSIONS OF THE EFFECT OF BRANCHING DEREGULATION ON QUALITY ATTRIBUTES

\begin{tabular}{|c|c|c|c|c|c|}
\hline \multirow[b]{3}{*}{ Explanatory Variable } & \multicolumn{5}{|c|}{ Dependent Variable } \\
\hline & $\begin{array}{c}\text { Employees } \\
\text { per } \\
\text { branch }\end{array}$ & $\begin{array}{l}\text { Branch } \\
\text { density }\end{array}$ & $\begin{array}{c}\text { Bank's } \\
\text { age }\end{array}$ & $\begin{array}{c}\text { Salary } \\
\text { per } \\
\text { employee }\end{array}$ & $\begin{array}{c}\text { Number } \\
\text { of } \\
\text { states }\end{array}$ \\
\hline & (i) & (ii) & (iii) & (iv) & $(\mathrm{v})$ \\
\hline$N W B$ & $\begin{array}{l}-1.582 \\
(28.830)\end{array}$ & $\begin{array}{c}0.0005 \\
(0.0006)\end{array}$ & $\begin{array}{c}0.8062 \\
(1.6563)\end{array}$ & $\begin{array}{c}2.3175 \\
(1.2818) \dagger\end{array}$ & $\begin{array}{c}0.5435 \\
(0.1859) * *\end{array}$ \\
\hline One year after $N W B$ & $\begin{array}{c}35.626 \\
(26.452)\end{array}$ & $\begin{array}{l}0.0015 \\
(0.0005) * *\end{array}$ & $\begin{array}{c}-1.3413 \\
(1.5197)\end{array}$ & $\begin{array}{c}-0.6929 \\
(1.1761)\end{array}$ & $\begin{array}{l}0.8736 \\
(0.1706) * *\end{array}$ \\
\hline Two years after $N W B$ & $\begin{array}{c}42.081 \\
(26.452)\end{array}$ & $\begin{array}{c}-0.0001 \\
(0.0005)\end{array}$ & $\begin{array}{c}1.3718 \\
(1.5197)\end{array}$ & $\begin{array}{c}0.2192 \\
(1.1761)\end{array}$ & $\begin{array}{l}0.8103 \\
(0.1706) * *\end{array}$ \\
\hline Three years after $N W B$ & $\begin{array}{l}-4.919 \\
(36.123)\end{array}$ & $\begin{array}{c}-0.0001 \\
(0.0007)\end{array}$ & $\begin{array}{c}1.1979 \\
(2.0753)\end{array}$ & $\begin{array}{c}0.8873 \\
(1.606)\end{array}$ & $\begin{array}{l}1.4147 \\
(0.2330) * *\end{array}$ \\
\hline Time trend & $\begin{array}{r}-14.631 \\
(25.628)\end{array}$ & $\begin{array}{r}-0.0001 \\
(0.0005)\end{array}$ & $\begin{array}{c}1.6601 \\
(1.4724)\end{array}$ & $\begin{array}{c}1.2127 \\
(1.1394)\end{array}$ & $\begin{array}{c}-0.3460 \\
(0.1653) *\end{array}$ \\
\hline F-statistic & $9.35^{* *}$ & $17.57^{* *}$ & 2.23 & $6.17^{*}$ & $560.40^{* *}$ \\
\hline Observations & 357 & 357 & 357 & 357 & 357 \\
\hline Adj. R-squared & 0.94 & 0.97 & 0.88 & 0.70 & 0.83 \\
\hline
\end{tabular}

NOTES.-

1. NWB: Nationwide branching deregulation indicator which takes the value of one starting the year in which the state passes the Riegle-Neal Act.

2. Sample: 1993-1999.

3. An observation is an state* year combination.

4. The dependent variable is a deposit market share weighted average of all banks in a given state.

5. All regressions include state fixed effects and a state-specific trend.

6. Salary per employee in thousands.

7. Value of F-statistic for the test of whether the sum of the deregulation indicators equals zero.

8. Estimated standard errors are in parentheses.

9. †ंsignificant at $10 \%$; *significant at $5 \%$; ${ }^{* *}$ significant at $1 \%$. 
Table 14: PRICES, COST, RISK AND PERFORMANCE BEFORE AND AFTER NATIONWIDE BRANCHING

\begin{tabular}{|c|c|c|c|c|c|}
\hline \multirow[b]{2}{*}{ Variable } & \multicolumn{2}{|c|}{1993} & \multicolumn{2}{|c|}{1999} & \multirow[b]{2}{*}{ T-stat } \\
\hline & Mean & St. Dev. & Mean & St. Dev. & \\
\hline Loan interest rate & 0.0894 & 0.0162 & 0.0848 & 0.0303 & -9.53 \\
\hline Deposit interest rate & 0.0287 & 0.0073 & 0.0323 & 0.0081 & 23.09 \\
\hline Service fees & 0.0061 & 0.0048 & 0.0074 & 0.1398 & 0.65 \\
\hline Spread & 0.0668 & 0.0184 & 0.0599 & 0.1426 & -3.53 \\
\hline Operating costs & 0.0401 & 0.0339 & 0.0372 & 0.0366 & -4.15 \\
\hline Credit risk & 0.0032 & 0.0105 & 0.0017 & 0.0045 & -8.87 \\
\hline Profit margin & 0.1200 & 0.1524 & 0.1108 & 0.1130 & 1.21 \\
\hline Observations & 5293 & & 4536 & & \\
\hline
\end{tabular}


Table 15: OLS REGRESSIONS OF THE EFFECT OF BRANCHING DEREGULATION ON PRICES

\begin{tabular}{|c|c|c|c|c|}
\hline \multirow[b]{3}{*}{ Explanatory Variable } & \multicolumn{4}{|c|}{ Dependent Variable } \\
\hline & Loan rate & Deposit rate & Service fees & Spread \\
\hline & (i) & (ii) & (iii) & (iv) \\
\hline$N W B$ & 0.0017 & 0.0027 & 0.0001 & -0.0010 \\
\hline & $(0.0011)$ & $(0.0008) * *$ & $(0.0001)$ & $(0.0007)$ \\
\hline One year after $N W B$ & -0.0010 & 0.0008 & 0.0001 & -0.0019 \\
\hline & $(0.0011)$ & $(0.0008)$ & $(0.0001)$ & $(0.0007) * *$ \\
\hline Two years after $N W B$ & -0.0021 & -0.0009 & 0.0002 & -0.0011 \\
\hline & $(0.0011) *$ & $(0.0008)$ & $(0.0001) *$ & $(0.0007) \dagger$ \\
\hline Three years after $N W B$ & -0.0025 & -0.0002 & 0.0000 & -0.0027 \\
\hline & $(0.0016)$ & $(0.0012)$ & $(0.0001)$ & $(0.0009) * *$ \\
\hline Time trend & 0.0018 & 0.0004 & -0.0001 & 0.0014 \\
\hline & $(0.0010) \dagger$ & $(0.0008)$ & $(0.0001)$ & $(0.0007) *$ \\
\hline Market rate & 0.1125 & 0.0923 & & \\
\hline & $(0.0508) *$ & $(0.0375) *$ & & \\
\hline F-statistic & $9.88^{* *}$ & $7.20^{* *}$ & $17.68^{* *}$ & $118.31^{* *}$ \\
\hline Observations & 357 & 357 & 357 & 357 \\
\hline Adj. R-squared & 0.64 & 0.63 & 0.91 & 0.80 \\
\hline
\end{tabular}

NOTES.-

1. NWB: Nationwide branching deregulation indicator which takes the value of one starting the year in which the state passes the Riegle-Neal Act.

2. Sample: 1993-1999.

3. An observation is an state*year combination.

4. The dependent variable is a deposit market share weighted average of all banks in a given state.

5. All regressions include state fixed effects and a state-specific trend.

6. Value of F-statistic for the test of whether the sum of the deregulation indicators equals zero.

7. The spread is calculated as loan rate + service fees - deposit rate.

8. Estimated standard errors are in parentheses.

9. †ंignificant at $10 \%$; *ignificant at $5 \%$; ** significant at $1 \%$. 
Table 16: OLS REGRESSIONS OF THE EFFECT OF BRANCHING DEREGULATION ON COSTS, RISK AND PERFORMANCE

\begin{tabular}{|c|c|c|c|}
\hline \multirow[b]{3}{*}{ Explanatory Variable } & \multicolumn{3}{|c|}{ Dependent Variable } \\
\hline & Costs & $\begin{array}{c}\text { Credit } \\
\text { risk }\end{array}$ & $\begin{array}{c}\text { Profit } \\
\text { margin }\end{array}$ \\
\hline & (i) & (ii) & (iii) \\
\hline$N W B$ & $\begin{array}{c}0.0017 \\
(0.0012)\end{array}$ & $\begin{array}{l}0.0009 \\
(0.0003) * *\end{array}$ & $\begin{array}{c}0.0005 \\
(0.0080)\end{array}$ \\
\hline One year after $N W B$ & $\begin{array}{c}0.0025 \\
(0.0011) *\end{array}$ & $\begin{array}{l}0.0006 \\
(0.0003) *\end{array}$ & $\begin{array}{c}-0.0079 \\
(0.0074)\end{array}$ \\
\hline Two years after $N W B$ & $\begin{array}{c}0.0024 \\
(0.0011) *\end{array}$ & $\begin{array}{l}0.0010 \\
(0.0003) * *\end{array}$ & $\begin{array}{c}-0.0106 \\
(0.0074)\end{array}$ \\
\hline Three years after $N W B$ & $\begin{array}{l}0.0056 \\
(0.0015) * *\end{array}$ & $\begin{array}{l}0.0015 \\
(0.0004) * *\end{array}$ & $\begin{array}{r}-0.0110 \\
(0.0101)\end{array}$ \\
\hline Time trend & $\begin{array}{c}-0.0028 \\
(0.0011) *\end{array}$ & $\begin{array}{c}-0.0008 \\
(0.0003) * *\end{array}$ & $\begin{array}{c}0.0098 \\
(0.0072)\end{array}$ \\
\hline F-statistic & $19.31^{* *}$ & $143.67^{* *}$ & $272.16^{* *}$ \\
\hline Observations & 357 & 357 & 357 \\
\hline Adj. R-squared & 0.72 & 0.70 & 0.58 \\
\hline
\end{tabular}

NOTES.-

1. NWB: Nationwide branching deregulation indicator which takes the value of one starting the year in which the state passes the Riegle-Neal Act.

2. Sample: 1993-1999.

3. An observation is an state*year combination.

4. The dependent variable is a deposit market share weighted average of all banks in a given state.

5. All regressions include state fixed effects and a state-specific trend.

6. Value of F-statistic for the test of whether the sum of the deregulation indicators equals zero.

7. Estimated standard errors are in parentheses.

7. † †significant at $10 \%$; *significant at $5 \%$; ** significant at $1 \%$. 


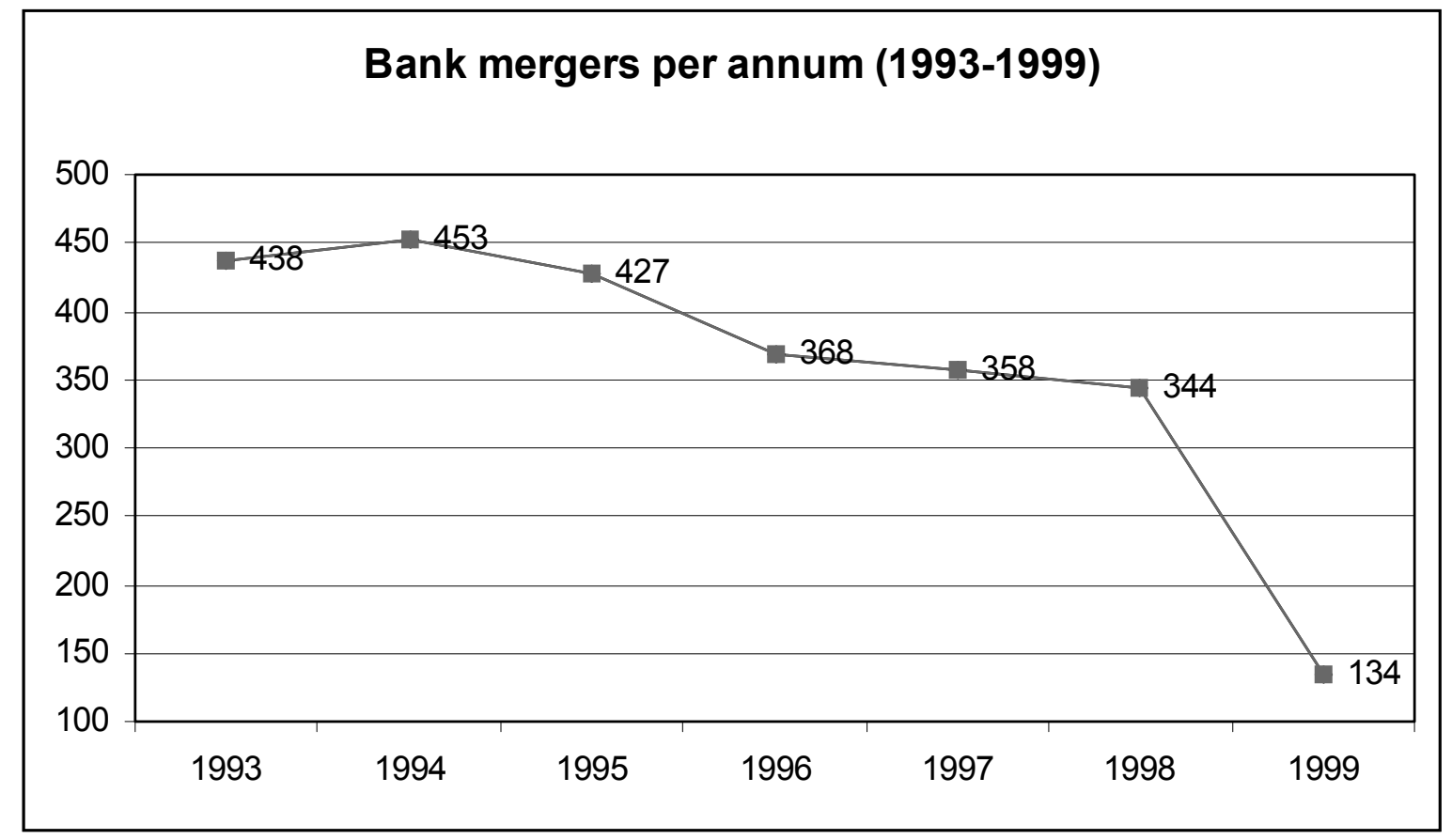

Figure 1: 


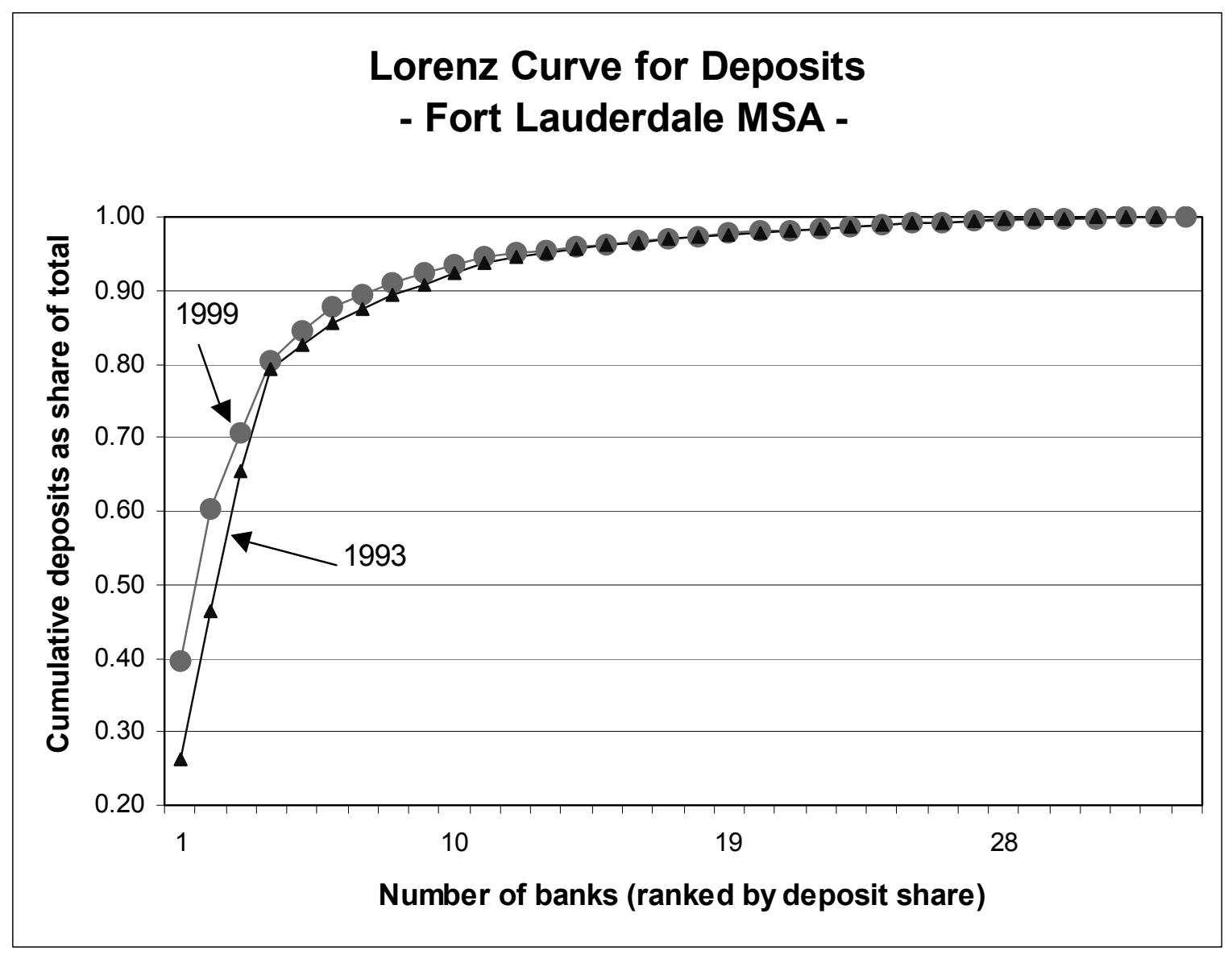

Figure 2: 


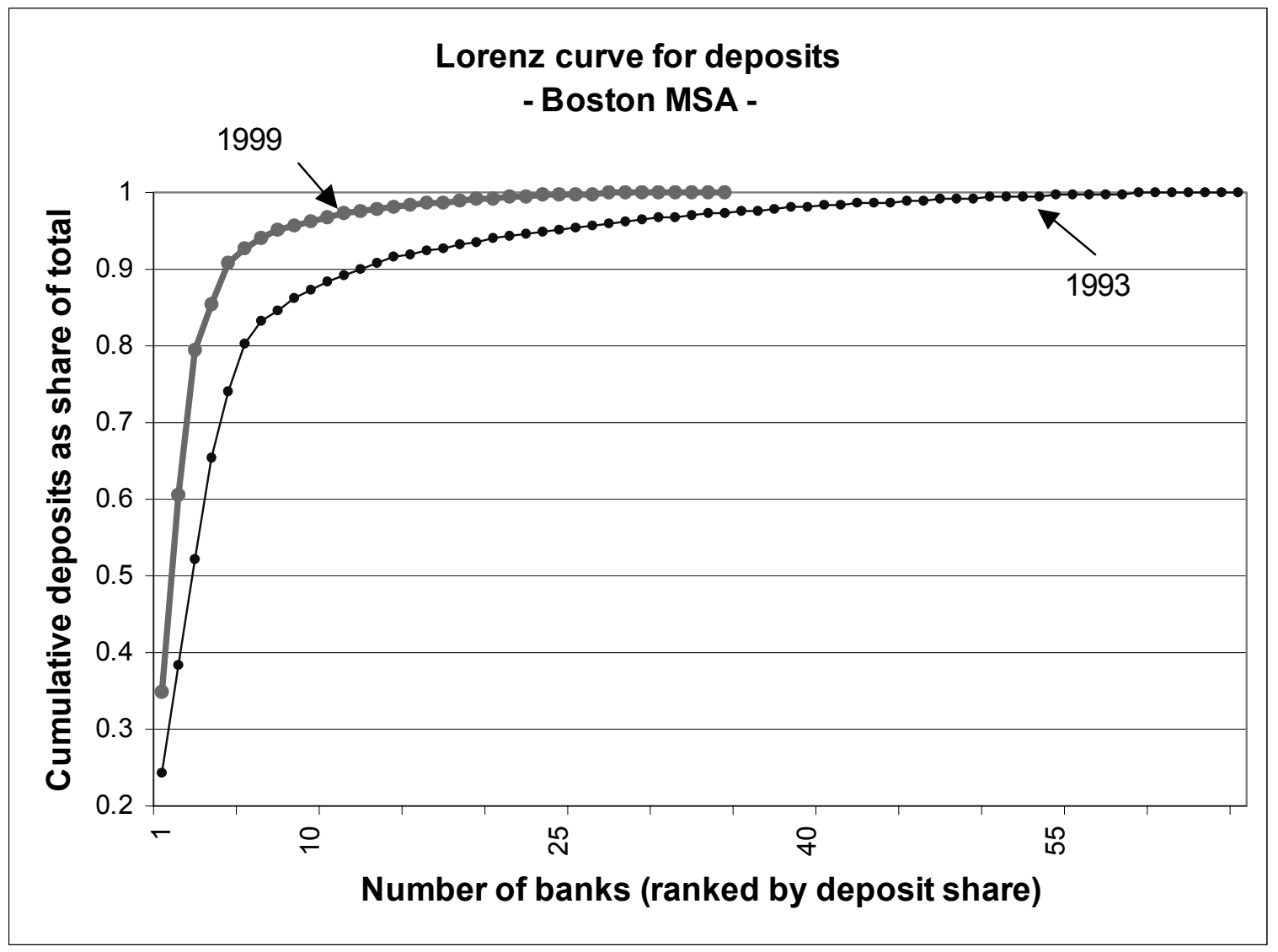

Figure 3: 


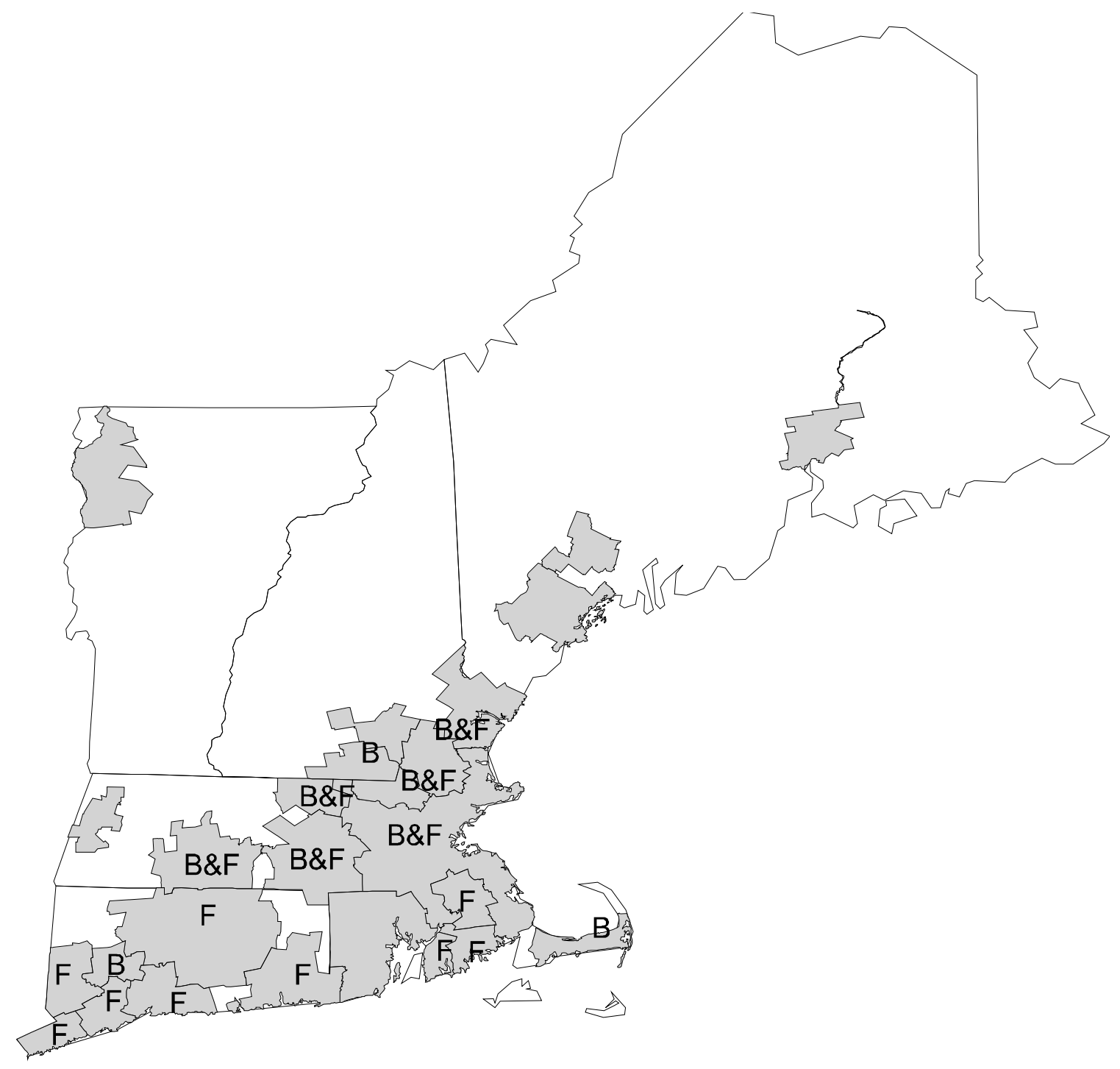

REGIONAL DOMINANT FIRMS ACROSS MSA'S IN NEW ENGLAND $(\mathrm{B}=\mathrm{BANKBOSTON}, \mathrm{F}=\mathrm{FLEET}$ )

Figure 4: 


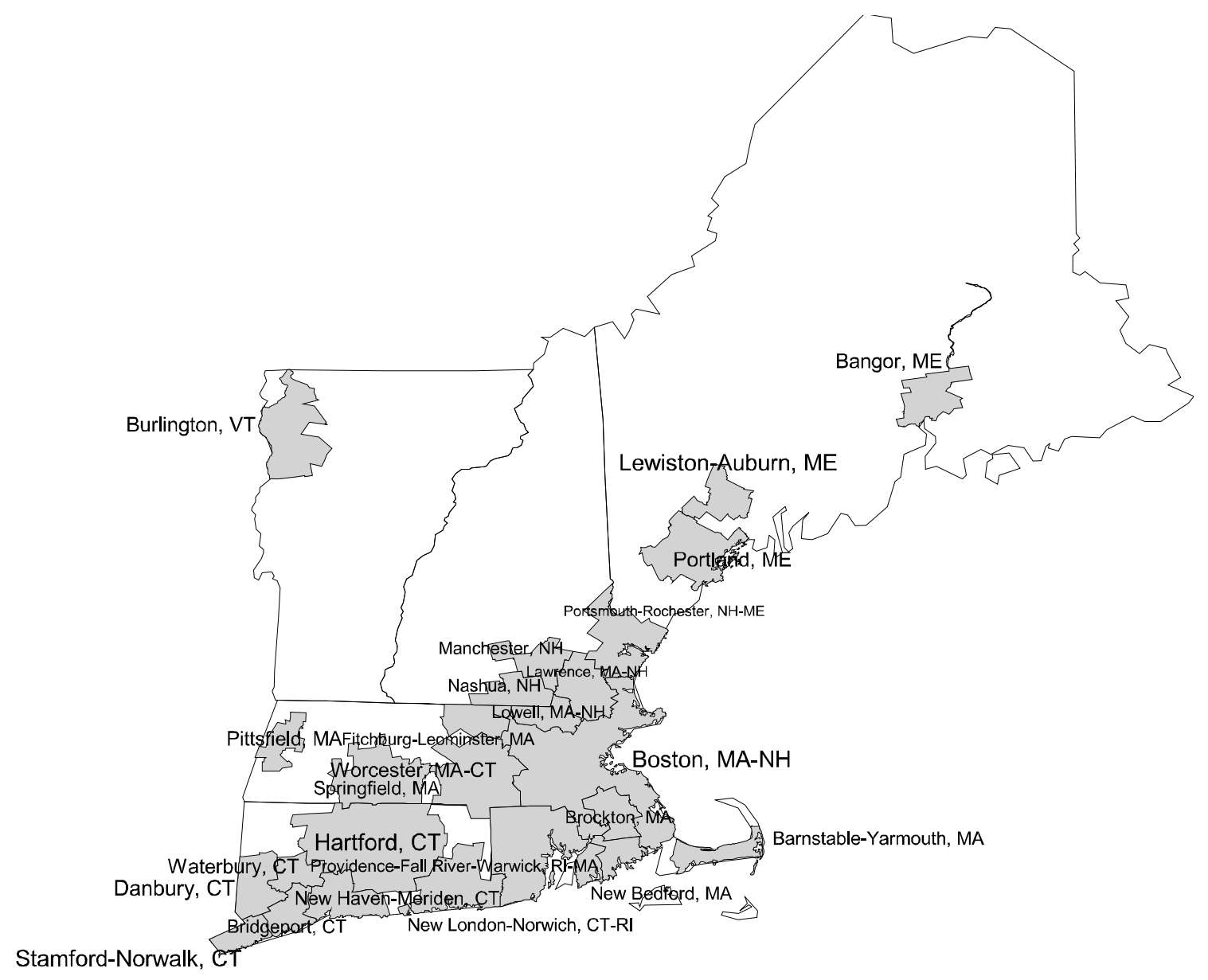

\section{MSA MARKETS WITHIN THE NEW ENGLAND REGION}

Figure 5: 
APPENDIX: DESCRIPTION OF VARIABLES

\begin{tabular}{ll}
\hline \hline Variable & Description \\
Service fees & Service charges on deposit accounts / De- \\
& posits \\
Deposit interest rate & Interest expense on deposits (includes in- \\
& terest on time, savings and NOW ac- \\
& counts / Deposits \\
Loan interest rate & Interest income on loans / Loans \\
Employees per branch & Number of bank employees / Number of \\
& branches \\
Branch density & Number of branches in local market / \\
& Square miles of local market \\
Bank's age & Years since beginning of bank's opera- \\
& tions \\
Number of states & Number of states where the bank has \\
Operating costs & branch offices \\
& Expenses including salaries, expenses on \\
Credit risk & premises and fixed assets, and other ex- \\
Bank operates in at least one rural market (1=yes) & penses \\
& Charge-off losses / Loans \\
& Whether bank operates in at least one \\
& non-MSA rural county \\
\hline
\end{tabular}

